\title{
Choice of microhabitat in tactile foraging dunlins Calidris alpina: the importance of sediment penetrability
}

\author{
K. N. Mouritsen, K. T. Jensen \\ Institute of Biological Sciences, Department of Ecology and Genetics, University of Aarhus, Ny Munkegade, \\ DK-8000 Aarhus C, Denmark
}

\begin{abstract}
Tactile-searching dunlins Calidris alpina fed selectively in small-scale depressions on an intertidal mudflat in the Danish Wadden Sea. This choice of microhabitat could be related to higher sediment penetrability in depressions compared with the surrounding flats, allowing the peck depth to be doubled. A model is presented describing the probability of dunlins detecting the predominant prey item Hydrobia ulvae as a function of peck depth. The model predicts that the increased peck depth in depressions would improve foraging success 4 -fold. It is suggested that the presence of depression and the accompanying increase in sediment penetrability not only account for the selection of microhabitat but also affect the distribution of dunlins on a larger spatial scale.
\end{abstract}

\section{INTRODUCTION}

Despite their often uniform appearance, intertidal mudflats exhibit considerable small-scale heterogeneity with regard to both sediment characteristics and invertebrate distribution (Trush et al. 1989, Trush 1991). The ability of foraging shorebirds to recognize and explore microhabitats within such a variable environment may be essential for them to optimize net energy intake (e.g. Myers et al. 1980, Quammen 1982, Grant 1984). Microspatial pattern in sediment firmness, for instance, could be important for tactilesearching birds which may invest considerable energy in penetrating the substrate to locate buried prey items (e.g. Pienkowski 1981). Because of the hierarchical organization of patches in nature, a preference for certain microhabitats could also affect the distribution of shorebirds on a larger spatial scale (Morris 1987. Kotliar \& Wiens 1990). Identification of factors responsible for the selection of microhabitats by shorebirds is therefore important for our understanding of their distribution and of how they perceive their immediate surroundings.

On an intertidal mudflat subjected to prolonged emersion, we observed that dunlins Calidris alpina selected small-scale sediment depressions as feeding sites. Among possible abiotic and biotic factors characterizing the depressions relative to the surrounding flats, sediment penetrability affecting peck depth was found to be a key factor responsible for their preference. To support this, the effect of varying peck depth on the detectability of the predominant prey organism, Hydrobia ulvae, was quantified.

\section{MATERIAL AND METHODS}

Study area. Studies were carried out in the southern part of the Danish Wadden Sea $\left(54^{\circ} 56^{\prime} N, 8^{\circ} 39^{\prime}\right.$ E) in autumn 1989 (the main study period) and 1990. The study site was located $400 \mathrm{~m}$ seaward of MHWL on a mudflat with an intertidal width of about $1500 \mathrm{~m}$. At the study site conspicuous depressions (mainly old feeding pits made by e.g. shelduck Tadorna tadorna) occurred abundantly. When the survey was started in 1989, the study site had not been inundated for approximately $48 \mathrm{~h}$ due to strong offshore winds. Although the sediment surface was desiccated, dunlins were foraging at this upper shore level and virtually nowhere else in the intertidal zone. 
Foraging effort and success. Owing to the dry sediment surface, all peck marks made by the dunlins were preserved in the sediment. To measure foraging effort the density of peck marks was estimated by using a small frame $\left(2.8 \mathrm{~cm}^{2}\right)$ thrown at random in 13 randomly selected depressions (40 to $480 \mathrm{~cm}^{3}$ ). The surrounding flats were monitored using a larger frame $\left(50 \mathrm{~cm}^{2}\right)$. Peck depth was measured in the field with a scaled stick, allowing depth to be determined to the nearest $0.5 \mathrm{~mm}$

Whenever a prey item had been removed by the birds, characteristic imprints that could be distinguished easily from peck marks were left behind in the sediment. Prey items, as well as foraging success per peck, were determined by the shape and density of such imprints. Identification of prey items was based on a reference to imprints produced when various prey species were removed experimentally by pincers. Foraging success was examined on the sediment surface areas $\left(50 \mathrm{~cm}^{2}\right)$ of 24 cores collected shortly afterwards (see below).

Prey density, profitability and availability. To determine the density of prey organisms within and outside depressions, cores $\left(50 \mathrm{~cm}^{2}, 25 \mathrm{~cm}\right.$ deep) were collected in 12 of the previously chosen depressions and also at 12 sites selected randomly on the surrounding flats. The cores were sieved through a $500 \mu \mathrm{m}$ screen and all organisms retained were fixed in $10 \%$ buffered formalin. Animals were counted and measured in the laboratory using a stereomicroscope. Calculations of ash-free dry weight (AFDW) were based on reported lengthweight equations: Hydrobia ulvae (Jensen 1980). Nereis diversicolor (Zwarts \& Esselink 1989), Macoma balthica (Rumohr et al. 1987), and Crangon crangon (Kuipers \& Dapper 1981).

The surface activity of invertebrates was determined by direct observations of the sediment surface within a $10 \times 10 \mathrm{~cm}$ frame; 3 depressions and 3 plots on the surrounding flats were monitored during 5 observation periods of $1 \mathrm{~min}$ each. In order to mimimize the influence of the observer on the behaviour of the animals, the sediment within a distance of about $60 \mathrm{~cm}$ from the observed area was left untouched. On several previous occasions, feeding amphipods, molluscs and polychaetes had been observed in this way without this causing them to cease foraging.

To estimate the accessibility of burrowed prey organisms to pecking dunlins, ten $50 \mathrm{~cm}^{2}$ cores, $6 \mathrm{~cm}$ deep, were collected both within and outside depressions in 1990. The sediment cores were brought undisturbed to the laboratory and were then well ventilated for $48 \mathrm{~h}$ at $20^{\circ} \mathrm{C}$ to simulate field conditions in 1989. The $3 \mathrm{~mm}$ surface layer (approximate maximum peck depth of dunlins) of each core was removed, and sieved through a $500 \mu \mathrm{m}$ screen. The next $2.7 \mathrm{~cm}$ of the sediment cores were treated likewise, adding up to $3 \mathrm{~cm}$ (approximate dunlin bill length). Retained animals were fixed in $80 \%$ ethanol and counted. The cores were left untouched until sliced, during which time the animals had the opportunity to take up their natural spatial position under the prevailing conditions. Although slicing the cores may cause tube-dwelling animals to retract, the presence of amphipods in the upper $3 \mathrm{~mm}$ sediment layer (see Table 2) suggests that this was not a serious problem. Thus, comparison of prey depth between treatments should be valid.

Since Hydrobia ulvae appeared to be the predominant prey species (see 'Results'), their availability to pecking dunlins was investigated in detail. The decisive factor for the availability of $H$. ulvae is the touchable shell area present in the sediment (Myers et al. 1980, Hulscher 1982). Assuming that a dunlin's bill approaches perpendicular to the sediment surface, the touch area of a $H$. ulvae specimen can be defined as the cross-sectional area in the horizontal plane. Thus, for a given peck depth the total touch area of $H$. ulvae specimens in the sediment depends on the density, the size distribution, the vertical distribution and the orientation of the $H$. ulvae individuals. The latter is due to the shape of the shell, which causes a horizontally orientated specimen to occupy a larger maximum touch area than individuals burrowed e.g. vertically (see box in Fig. 4). Knowing these parameters, a dunlin's probability of detecting a $H$. ulvae specimen by touch can be calculated.

In order to reveal the vertical distribution of burrowed Hydrobia ulvae specimens, $50 \mathrm{~cm}^{2}$ sediment cores were collected randomly in 5 depressions and in 5 plots on the surrounding flats. In the laboratory, the top $3 \mathrm{~cm}$ of the sediment cores was cut vertically into ca $0.5 \mathrm{~mm}$ slices using a scalpel. The burying depth (minimum distance to sediment surface) and shellheight of encountered individuals were measured using a slide caliper and stereomicroscope, respectively. Also, the orientation of burrowed specimens was recorded relative to the sediment surface, and assigned to one of 5 categories: (1) columella vertical (spire downwards); (2) columella $45^{\circ}$ (spire downwards); (3) columella horizontal; (4) columella $45^{\circ}$ (spire upwards); and (5) columella vertical (spire upwards).

The touch area of a Hydrobia ulvae specimen at different points of the cross-sections was determined using models (scale 1:12) constructed from 3 average size measurements: shell height, shell width and mouth height ( $\mathrm{n}=15$ for each mean). Models arranged in different orientations were cut horizontally into slices corresponding to $0.25 \mathrm{~mm}$ on the real specimen, until the largest cross-sectional area was 
achieved. At each cross-section the models were photographed, and the resulting areas were cut out and their weight measured. The cross-sectional areas were finally obtained for the real specimen by weightarea transformation.

Sediment analysis. Sediment cores $\left(24 \mathrm{~cm}^{2}, 3 \mathrm{~cm}\right.$ deep) were sampled at random in 5 depressions and at 5 sites on the surrounding flats. The silt content (particle size $<63 \mu \mathrm{m}$ ) was attained by wet sieving of oven dried sediment $\left(100{ }^{\circ} \mathrm{C}, 24 \mathrm{~h}\right)$ treated with $\left(\mathrm{NaPO}_{3}\right)_{6}\left(6.2 \mathrm{~g} \mathrm{l}^{-1}\right)$, according to Buchanan (1984). The sand fraction was further graded by dry sieving. In 1990, undisturbed sediment cores $\left(50 \mathrm{~cm}^{2}\right)$ were sampled in 5 depressions of approximately equal size and at 5 random sites on the surrounding flats. In the laboratory, the penetrability of the sediment was measured using a modified spring balance as a penetrometer (rod diameter: $3.5 \mathrm{~mm}$ ). The instrument was pushed into the sediment to $2 \mathrm{~mm}$ depth and the compressive strength read directly. In each core, 10 penetrometry measurements were performed after $48 \mathrm{~h}$ at $20^{\circ} \mathrm{C}$. In addition, one $4 \mathrm{~cm}^{2}$ core, $1 \mathrm{~cm}$ deep, was taken from each $50 \mathrm{~cm}^{2}$ core immediately after the penetrometry measurements, and water content was determined as weight loss after drying $\left(100^{\circ} \mathrm{C}, 24 \mathrm{~h}\right.$ ).

Random selection of sampling sites was achieved by throwing a rubber ball into the air, the site being selected in a predetermined direction and distance from where the rubber ball landed.

Statistical analysis. Statistical tests were performed according to Snedecor \& Cochran (1989) (parametric analysis) and Sokal \& Rohlf (1981) (nonparametric analysis).

\section{RESULTS}

\section{Foraging effort and success}

The foraging method used by dunlins was randomized pecking or more rarely stitching (Burton 1974), penetrating at most $3.5 \mathrm{~mm}$ into the sediment. Most foraging attempts $[92 \%$ in depressions $(n=50)$ and $84 \%$ on the surrounding flats $(n=50)$ ] were performed with open beaks, or rhynchokinesis (Pettigrew \& Frost 1985), this technique producing 2 marks per peck. The frequency of pecks made by opened beaks did not differ between habitats (2-tailed $z$-test, $z_{c}=0.92, \mathrm{p}=0.36$ ). The density of peck marks, however, was considerably higher in depressions than on the surrounding flats, and there was a strong positive correlation between mean peck density and the size of depressions (Fig. 1). The peck depth was on average $2.0 \mathrm{~mm}$ in depressions and $1.0 \mathrm{~mm}$ on the surrounding flats (Fig. 2). This difference in peck depth was highly significant (log-

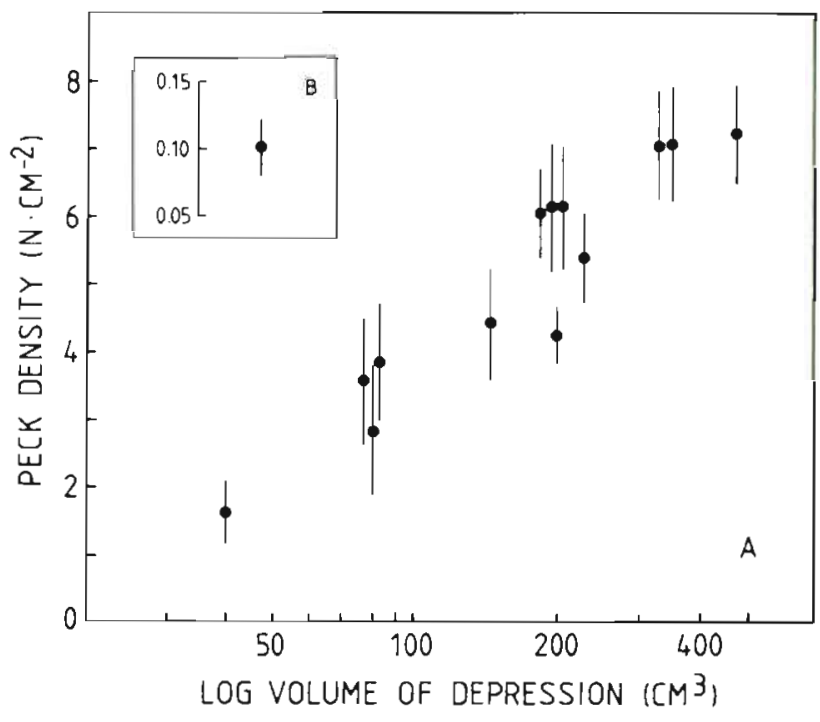

Fig. 1. Calidris alpina. (A) The density of peck marks made by dunlins (mean $\pm 95 \% \mathrm{CI}, \mathrm{n}=10$ ) as a function of the volume of depressions $\left(\mathrm{r}_{\mathrm{s}}=0.91, \mathrm{df}=11, \mathrm{p}<0.001\right)$. (B) Peck density on the surrounding flats (mean $\pm 95 \% \mathrm{CI}, \mathrm{n}=111$ )

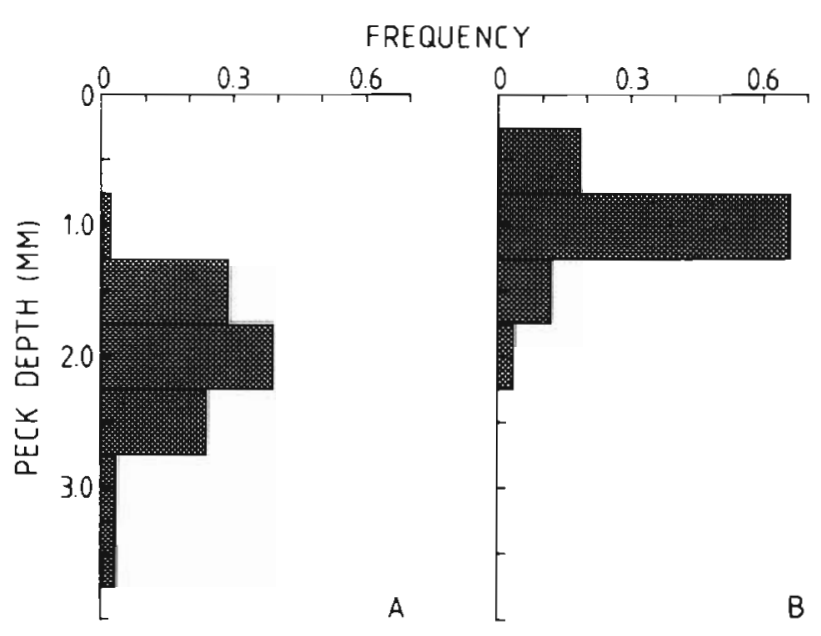

Fig. 2. Calidris alpina. Depth of pecks made by dunlins in (A) depressions and (B) on the surrounding flats. Mean values are $2.0 \mathrm{~mm} \pm 0.3(\mathrm{SD})(\mathrm{n}=93)$ and $1.0 \mathrm{~mm} \pm 0.1(\mathrm{n}=53)$, respectively

transformed data; $F$-test, $F_{92,58}=1.02, \mathrm{p}>0.05$, Student's $t$-test, $\left.t_{150}=13.29, \mathrm{p}<0.001\right)$.

Prey species taken by dunlins comprised Hydrobia ulvae, Macoma balthica and Crangon crangon. In total, $32 \mathrm{H}$. ulvae, $2 \mathrm{M}$. balthica and $2 \mathrm{C}$. crangon specimens were taken from the examined areas in the depressions. The foraging success on $H$. ulvae was on average 2.7 individuals per area \pm 2.8 (SD) (range: 0 to 8 ). In contrast, only $2 \mathrm{C}$. crangon were taken on the examined surrounding flats. 
Table 1. Density of invertebrates in depressions and in the surrounding flats. Values are means per $50 \mathrm{~cm}{ }^{2}( \pm \mathrm{SE})(\mathrm{n}=10)$. p: Mann-Whitney test. ns: non-significant $(p>0.05)_{i}{ }^{\circ} p<0.05_{i}{ }^{*} p<0.01$

\begin{tabular}{|c|c|c|c|}
\hline Species & Depressions & Surrounding flats & $\mathrm{p}$ \\
\hline Enchytraeidae indet. & $2.3(0.7)$ & $0.5 \quad(0.2)$ & ns \\
\hline Tubificoides benedeni & $28.8 \quad(5.5)$ & $16.0 \quad(1.2)$ & $\mathrm{ns}$ \\
\hline Capitella capitata & $0.3 \quad(0.2)$ & - & ns \\
\hline Eteone longa ${ }^{\dagger}$ & $0.6 \quad(0.2)$ & $0.6 \quad(0.3)$ & ns \\
\hline Heteromastus filiformis $^{\dagger}$ & $0.8 \quad(0.3)$ & $1.3 \quad(0.1)$ & ns \\
\hline Nereis diversicolor ${ }^{\dagger}$ & $1.3(0.3)$ & $0.3(0.1)$ & $\cdot$ \\
\hline Anaitides maculata ${ }^{\dagger}$ & - & $0.1 \quad(0.1)$ & ns \\
\hline Pygospio elegans & $5.1(1.0)$ & $12.7 \quad(2.2)$ & * \\
\hline Hydrobia ulvae & $60.0 \quad(5.3)$ & $57.3 \quad(2.7)$ & ns \\
\hline Macoma balthica & $4.6 \quad(0.8)$ & $2.5 \quad(0.3)$ & $\mathrm{ns}$ \\
\hline Mya arenana & - & $0.1 \quad(0.1)$ & ns \\
\hline Corophium volutator & - & $0.1 \quad(0.1)$ & ns \\
\hline Corophium arenarium & $0.5 \quad(0.2)$ & $3.2(0.6)$ & $\cdots$ \\
\hline Bathyporeia sp. & - & $0.3 \quad(0.2)$ & ns \\
\hline Crangon crangon & $0.9 \quad(0.3)$ & $0.2 \quad(0.2)$ & ns \\
\hline${ }^{\dagger}$ Larger polychaete worms combined & $2.3 \quad(0.3)$ & $3.0 \quad(0.4)$ & ns \\
\hline
\end{tabular}

\section{Prey density, profitability and availability}

Among the benthic invertebrates only Nereis diversicolor occurred in significantly higher densities inside the depressions than outside (Table 1). This pattern did not change if densities were corrected for removed prey individuals. Apart from Tubificoides benedeni, Pygospio elegans and Hydrobia ulvae, other species occurred in very low densities in both habitats.

The size-frequency distribution of relevant prey species was compared between habitats using 2 -tailed Kolomogorov-Smirnov test. No significant difference was found in Nereis diversicolor (length range: 0.2 to $8.1 \mathrm{~cm}, \mathrm{D} \mathrm{n}_{1} \mathrm{n}_{2}=14, \mathrm{p}>0.1$ ), Macoma balthica (length range: 0.8 to $24.0 \mathrm{~mm}, \mathrm{D}=0.15, \mathrm{p}>0.8$ ) and Crangon crangon (length range: 3.3 to $9.3 \mathrm{~mm}, \mathrm{Dn}_{1} \mathrm{n}_{2}=11, \mathrm{p}>$ $0.1)$. The size distribution of Hydrobia ulvae, in contrast, was significantly different ( $D=0.09, p<0.01$ ). Fewer of the smallest individuals $(<2 \mathrm{~mm})$ in the depressions accounted for this difference. In both habitats, however, the majority measured ca $4 \mathrm{~mm}$ in shell-height.

Observations of the sediment surface in depressions and on the surrounding flats did not reveal any invertebrate activity during the observation periods, nor were burrow holes indicating prey position evident at the surface. The proportion of invertebrate prey present in the top $3 \mathrm{~mm}$ of the sediment showed no significant difference between habitats in the 1990 samples (Table 2). Apart from Hydrobia ulvae and Macoma balthica, other encountered species were extremely rare in this surface layer. Nereis diversicolor and Crangon crangon were not found in densities adequate to assess their availability. The latter species, however, is considered to be immediately accessible to pecking dunlins. Although this analysis of prey availability does not necessarily reflect what the situation was in 1989, it seems reasonable to assume that any discrepancy between the habitats would be qualitatively the same in both years.

The more detailed analysis of the vertical distribution of the predominant prey Hydrobia ulvae showed no difference between habitats $\left(F\right.$-test, $F_{292,212}=1.02, \mathrm{p}$ $>0.05 ;$ Student's $t$-test, $t_{504}=0.62, p>0.5$ t the tests were confined to specimens in the top $4 \mathrm{~mm}$ of the sediment where the data were approximately normally distributed). Almost the entire population of burrowed specimens was situated in the uppermost $3 \mathrm{~mm}$, and therefore detectable to pecking dunlins (Fig. 3). No relationship between burrowing depth and shell-height could be demonstrated, either in depressions $\left(r^{2}=0.01\right.$, $\mathrm{df}=294, \mathrm{p}>0.1)$ or on the surrounding flats $\left(\mathrm{r}^{2}=0.01\right.$, $\mathrm{df}=221, \mathrm{p}>0.1$ )

The orientation of burrowed Hydrobia ulvae appeared to be non-random. Both in and outside depressions, individuals belonging to categories 1,2 and 3 predominated (>95\%) (see box in Fig. 4). In depressions, these 3 categories occurred in equal proportions (Chi-square test, $\chi^{2}=1.58$, df $=2, p>$ 0.25 ), whereas on the surrounding flats category 2 predominated at the expense of category 1. However, this difference in shell orientation between habitats would not affect the detectability of the gastropods, since the touch area of $H$. ulvae specimens belonging to categories 1 and 2 is almost identical (Fig. 4). The infrequent categories 4 and 5 were ignored, and the touch area of a $H$. ulvae specimen was determined as the mean of categories 1 to 3 in both habitats. Based upon the above findings, a 
Table 2. Density (mean per $50 \mathrm{~cm}^{2}, \mathrm{n}=10$ ) of invertebrates in the top $3 \mathrm{~cm}$ of the sediment (dunlins' maximum reach) and the proportional share (mean \%) registrated in the upper $3 \mathrm{~mm}$ (approx. dunlins' maximum peck depth). p: Mann-Whitney test between proportions in the upper $3 \mathrm{~mm}$. ns: non-significant $(p>0.05)$

\begin{tabular}{|lccccc|}
\hline \multirow{2}{*}{ Species } & \multicolumn{2}{c}{ Depressions } & \multicolumn{2}{c}{ Surrounding flats } \\
& Density & $\%$ & Density & $\%$ & \\
& & & & \\
& & & & \\
Tubificoides benedeni & 2.7 & 0 & 4.4 & 0 & $\mathrm{~ns}$ \\
Eteone longa & 2.0 & 2.3 & 2.8 & 1.7 & $\mathrm{~ns}$ \\
Nereis diversicolor & 0.1 & 0 & 0.1 & 0 & $\mathrm{~ns}$ \\
Pygospio elegans & 6.1 & 0 & 12.1 & 1.0 & $\mathrm{~ns}$ \\
Hydrobia ulvae & 17.1 & 79.5 & 17.1 & 70.6 & $\mathrm{~ns}$ \\
Macoma balthica & 3.7 & 15.0 & 6.0 & 23.3 & $\mathrm{~ns}$ \\
Corophium arenarium & 2.6 & 4.5 & 9.7 & 2.8 & \\
\hline
\end{tabular}

dunlin's probability $P$ of detecting a $H$. ulvae specimen with height $h$ by a single peck of depth $d$ can be calculated according to the formula:

$$
P=r D \sum_{i=0}^{4 d} q_{\mathrm{n}} a_{\mathrm{m}}
$$

where $r=$ frequency of specimens with height $h$ in the sample; $D=$ density of $H$. ulvae in the sample (n $\mathrm{mm}^{-2}$ ); $d=$ peck depth $(\mathrm{mm}) ; q_{\mathrm{n}}=$ frequency of specimens with height $h$ in the depth $n=0.25 i_{;} a_{\mathrm{m}}$ $=$ mean touch area $\left(\mathrm{mm}^{2}\right)$ of the categories 1 to 3 in the cross-sectional point $\mathrm{m}=d-0.25 i+0.25$. It was assumed that the $H$. ulvae individuals do not burrow beneath each other, and that the manner of orientation is independent of burying depth within

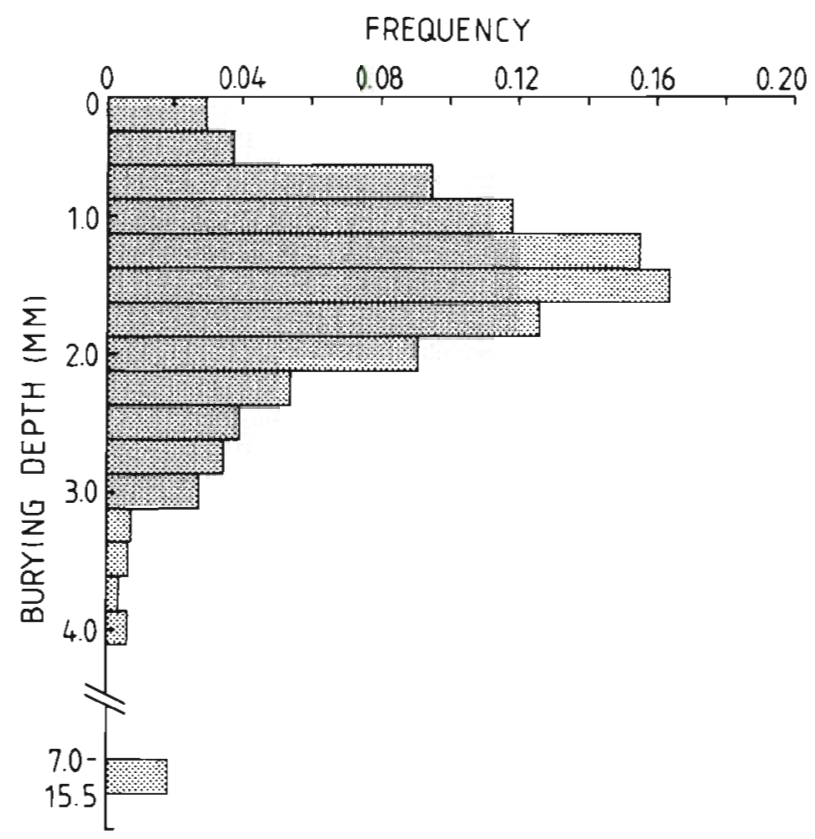

Fig. 3. Hydrobia ulvae. Burying depth based upon pooled data from depressions and the surrounding flats $(\mathrm{n}=517)$ dunlins' peck range. These assumptions were fulfilled in the $500 \mathrm{~cm}^{2}$ sediment analyzed here. For application of the model (here using $0.25 \mathrm{~mm}$ intervals of both peck depth and burying depth), a shell-height of $4.0 \mathrm{~mm}$ was used as representative for the $H$. ulvae population. In the pooled size-frequency distribution ( $\mathrm{n}=729$, data not shown) this height equals the mean of individuals measuring 3.0 to $5.0 \mathrm{~mm}$. As well as comprising the largest individuals, this group of specimens constituted $2 / 3$ of the entire population and therefore dominates the overall touch area in the sediment. Thus, $r$ equals $2 / 3$ and $a$ is derived from Fig. 4. The density $D$ is derived from Table 1 as the mean value between habitats, and $q$ is derived from the pooled vertical

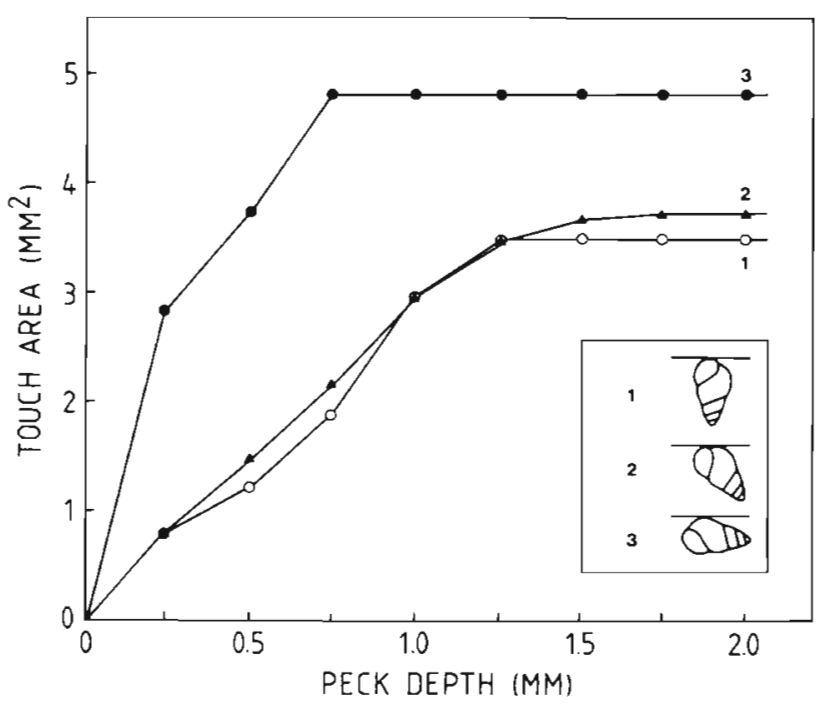

Fig. 4. Hydrobia ulvae. Touch area of a specimen as a function of depth (shell-height $=4.0 \mathrm{~mm}$, burying depth $=0$ ) belonging to the most frequent categories of orientation: (1) vertical, spire downwards; (2) $45^{\circ}$ spire downwards; (3) horizontal. The abscissa corresponds to the cross-sectional point, $\mathrm{m}$, indicated in the model (see text) 


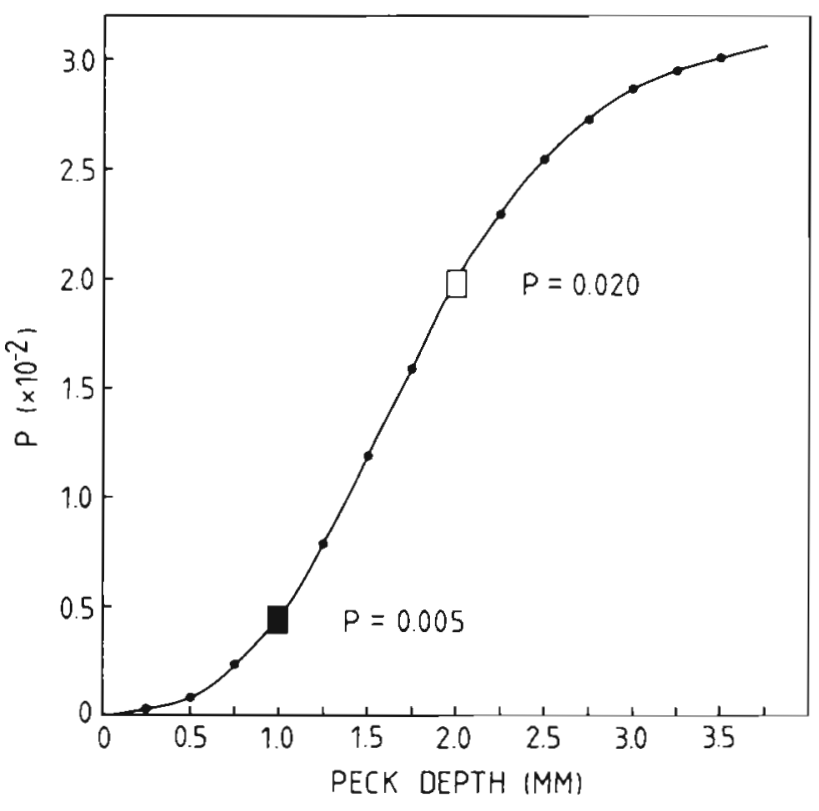

Fig. 5. Calidris alpina. A dunlin's probability $(P)$ of detecting a burrowed Hydrobia ulvae specimen by a single peck ( 1 hole only) as a function of peck depth. The curve is derived from Eq. (1) where $h=4.0 \mathrm{~mm}, r=2 / 3, D=0.012 \mathrm{~mm}^{-2}$ (mean density of microhabitats), $a=$ mean touch area $\left(\mathrm{mm}^{2}\right)$ of categories 1 to 3 (Fig. 5) and $q$ is obtained from Fig. 4. $\square$ and $\square$ : the dunlins' mean peck depth in depressions and on the surrounding flats, respectively

distribution (Fig. 3). As shown in Fig. 5, a dunlin's probability of detecting a $H$. ulvae specimen by pecking at random would be up to 4 times higher in depressions compared with the surrounding flats due to a larger peck depth in the former. Based upon these theoretical values and the observed peck densities, the expected foraging success was obtained for each of the 12 censused areas in the depressions. Expected success ranged between 1.6 and 7.1 individuals per area, and hence generally agreed with the observed foraging success ranging between 0 to 8 individuals per area.

\section{Sediment analysis}

Sediments from the 2 habitats were very similar according to granulemetric properties, whereas penetrability and water content were significantly higher in depressions (Table 3).

Unfortunately, a penetrometer suitable for fine scaled measurements was not available in 1989, and data on penetrability and water content were obtained the following year. We consider, however, that the observed difference between the habitats regarding those parameters would not differ between the years, at least in qualitative terms.

Penetrability measurements were compared using 1way ANOVA (nested model). Homogeneity of variance was confirmed by Levine's test $(p>0.05)$. The penetrability of the sediment was significantly different between habitats $\left(F_{1,8}=105.2, \mathrm{p}<0.001\right)$, but also within habitats $\left(F_{8,90}=8.1, p<0.01\right)$. Despite this intra-habitat variation, data were pooled to obtain a single mean value for each habitat (Table 3).

\section{DISCUSSION}

The field condition (desiccated mudflat) in the present investigation allowed us to study the behaviour of dunlins using tactile foraging alone. Swift and shallow pecking by e.g. rhynchokinesis, maximizing the rate of prey encounter, is probably the only feasible feeding method that could be adopted by dunlins during the prevailing conditions. No surface activity of invertebrates was observed which could promote visual prey detection. Furthermore, the proportion of pecks performed with closed bill, that might be interpreted as pecks directed visually against some sediment cues, was low and showed no significant difference between habitats. These circumstances made possible a direct comparison of foraging effort between depressions and the surrounding flats.

Table 3. Sediment properties within and outside depressions. Values are means ( \pm SD). Penetrability data were compared using a nested 1-way ANOVA $(\mathrm{n}=50)$, whereas the other parameters were compared by a Mann-Whitney test ( $\mathrm{n}=5$ ). ns: nonsignificant $(p>0.05) ; " p<0.01 ; \cdots p<0.001$. Smaller penetrability values indicate softer sediment

\begin{tabular}{|c|c|c|c|c|c|}
\hline \multirow{2}{*}{$\begin{array}{l}\text { Parameter } \\
\text { Penetrability }\left(\mathrm{kg} \mathrm{cm}^{-2}\right)\end{array}$} & \multicolumn{2}{|c|}{ Depressions } & \multicolumn{2}{|c|}{ Surrounding flats } & \multirow{2}{*}{$\begin{array}{l}\mathrm{p} \\
\end{array}$} \\
\hline & 2.5 & $(0.3)$ & 4.8 & $(0.5)$ & \\
\hline Water content ${ }^{a}(\%$ wt $)$ & 22.3 & (6.4) & 12.8 & (1.5) & • \\
\hline Silt content ${ }^{b}(<63 \mu \mathrm{m}, \%$ wt $)$ & 8.1 & $(1.2)$ & 6.4 & $(0.8)$ & ns \\
\hline Sand content ${ }^{b}(>500 \mu \mathrm{m}, \%$ wt) & 0.3 & $(0.1)$ & 0.2 & $(0.0)$ & ns \\
\hline Median particle diameter $(\phi)^{\mathrm{b}}$ & 2.75 & $(0.07)$ & 2.76 & $(0.06)$ & ns \\
\hline
\end{tabular}


Hydrobia ulvae, Macoma balthica and Crangon crangon were numerically the most important prey species, undoubtedly as a result of their relatively high availability in the upper sediment strata. However, none of the species listed in Table 1 can account directly for the dunlins' choice of microhabitat. Apart from Nereis diversicolor, there was no significant higher density of infaunal organisms in depressions compared with the surrounding flats, and no major differences in size distribution and/or relative availability were observed. Although dunlins often prey on $N$. diversicolor (e.g. Worrall 1984), the density of this species is an unlikely explanation of the birds' patch selection. Probe marks or worm shaped imprints, indicating that polychate worms had been taken, were never found in the depressions inspected. Moreover, according to Esselink \& Zwarts (1989) N. diversicolor specimens longer than $6 \mathrm{~cm}$ burrow deeper than $1 \mathrm{~cm}$ and are likely to be beyond the reach of pecking dunlins in this desiccated sediment. Disregarding these larger individuals the AFDW of $N$. diversicolor found in the samples is on average $1.6 \mathrm{mg} \pm 2.7(\mathrm{SD})(\mathrm{n}=19)$, approximately of the same order of magnitude as the AFDW of $H$. ulvae $(0.9 \mathrm{mg}$, shell-height $=4.0 \mathrm{~mm}), M$. balthica $[0.9 \mathrm{mg} \pm 1.2, \mathrm{n}=59$; specimens less than $10 \mathrm{~mm}$ in length, which may be the only individuals dunlins can swallow (Worrall 1984)] and C. crangon (0.3 mg $\pm 0.3, n=13)$. Concerning the low density of $N$. diversicolor compared with e.g. H. ulvae (Table 1 ), the former would have only little importance to the dunlins' energy intake, and is unlikely to account for the selection of microhabitat. Even if all observed prey captures had been specimens of $N$. diversicolor (e.g. 0.2 to $1.0 \mathrm{~cm}$ in length which is a typical size in this study), the higher initial density of $N$. diversicolor would still render it much more likely to detect $H$. ulvae specimens rather than $N$. diversicolor specimens. Also the pooled density of larger polychate worms, which may be a more relevant quantity to feeding dunlins, showed no significant difference between habitats (Table 1). Nor do biotic factors account for the increased foraging effort by dunlins with increasing size of depressions. Zero or negative correlations existed between foraging effort and the density of $N$. diversicolor $\left(r_{s}=0.15, p>0.1\right), H$. ulvae $\left(r_{3}=-0.46, p>0.1\right), M$. balthica $\left(\mathrm{r}_{\mathrm{s}}=-0.70, \mathrm{p}<0.02\right)$ and $C$. crangon $\left(\mathrm{r}_{\mathrm{s}}=0.17\right.$, $p>0.1)$ as well as for those species' pooled AFDW $\left(r_{s}=\right.$ $-0.43, p>0.1$ ) ( $d f=10$ for all coefficients).

Instead, abiotic factors such as sediment penetrability and water content could have a direct effect upon habitat selection by shorebirds. Sediment penetrability may significantly affect probing depth or the cost of foraging in tactile-searching birds which continuously penetrate the sediment in an attempt to detect infaunal prey. Hence, it might be expected that tactile feeders select habitats with high sediment penetrability either to (1) penetrate deeper into the sediment and thereby experience increased prey availability and profitability (see Readings \& McGrorty 1978, Esselink \& Zwarts 1989, Zwarts \& Wanink 1991), or (2) minimize foraging costs (Grant 1984). In experimental work under aviary conditions, Myers et al. (1980) showed that the foraging success of sanderlings Calidris alba decreased with decreasing sediment penetrability, owing to reduced probing depth in the firmer sediment. In a field study, Grant (1984) suggested that the selection of tidally formed ripple crests rather than troughs as probing sites by short-billed dowitchers Limnodromus griseus was caused by higher sediment penetrability in the crests, reducing the energy expenditure by the bird. On a larger spatial scale, Tjallingii (1972) found that the distribution of avocets Recurvirostra avocetta was determined by the resistance of the sediment to bill movements rather than by prey density. Kelsey \& Hassall (1989) have likewise argued that the distribution of dunlins on a heterogeneous mudflat was influenced by sediment penetrability. Notwithstanding that these studies stress the potential importance of sediment penetrability per se as a distributional factor, it remains to be shown that shorebirds actually select among otherwise identical habitats on the basis of sediment penetrability alone, and thereby optimize the probability of prey encounter. The present results support such an interpretation. Sediment penetrability and water content were significantly higher in depressions compared to the adjacent bottom (Table 3). Assuming that dunlins are pecking by constant force, the penetrability of the sediment will dictate peck depth and, hence, the probability of prey detection. In the case of Hydrobia ulvae as the main prey, the higher penetrability in depressions may cause a 4 times greater foraging success for dunlins (Fig. 5).

Since penetrability and water content are positively correlated (e.g. Chapman 1949, Perkins 1958, Grant 1984, Mouritsen unpubl.), the higher penetrability in depressions could be caused by higher water content. The longer residence time of water in depressions than on the surrounding flats may account for the difference in water content, and in turn, penetrability between the 2 habitats. Additionally, this might also explain the dunlins' preference for larger depressions (Fig. 1). Although high water content in the substrate has been reported to promote prey activity (Vader 1964, Evans 1979, Pienkowski 1981, 1983, Boates \& Smith 1989), this was not the case here. Neither surface activity nor accessibility of prey in the upper sediment strata was influenced by the difference in water content between habitats. The water content measured is probably far below the level that significantly promotes the activity of benthic organisms. 
The present results suggest that dunlins are able to respond to fine-scaled differences in sediment penetrability to optimize peck depth and thereby attain higher prey accessibility. In an experimental study under aviary conditions, Gerritsen \& von Heezik (1985) showed that dunlins preferred to feed upon soft sediment rather than firmer substrate types, even if this choice reduced their foraging success. These findings support the contention that sediment features have high priority in habitat selection by dunlins, and suggest that the birds actually assess sediment properties rather than respond directly to changes in foraging success. As a distributional factor, sediment penetrability may affect the birds' distribution also on a larger spatial scale. It is here suggested that the depressions and the accompanying higher sediment penetrability not only determined the dunlins' choice of microhabitat, but also caused their presence on the desiccated upper shore level, an area that from all a priori expectations should be avoided by any shorebírd.

Acknowledgements. We thank J. Madsen and reviewers for critical comments on an earlier draft, and E. Larsen for technical assistance. This study was supported by a grant from the Carlsberg Foundation (K.N.M.).

\section{LITERATURE CITED}

Boates, J. S., Smith, P. C. (1989). Crawling behaviour of the amphipod Corophium volutator and foraging by semipalmated sandpipers, Calidris pusilla. Can. J. Zool. 67 : $457-462$

Buchanan, J. B. (1984). Sediment analysis. In: Holmes, N. A., McIntyre, A. D. (eds.) Methods for the study of marine benthos. Blackwell Scientific Publications, Oxford, p. $41-65$

Burton, P. J. K. (1974). Feeding and the feeding apparatus in waders. Trustees of the British Museum (Natural History), London

Chapman, M. A. G. (1949). The thixotropy and dilatancy of marine soil. J. mar. biol. Ass. U.K. 28: 123-140

Esselink, P., Zwarts, L. (1989). Seasonal trend in burrow depth and tidal variation in feeding activity of Nereis diversicolor. Mar. Ecol. Prog. Ser. 56: 243-254

Evans, P. R. (1979). Adaptations shown by foraging shorebirds to cyclical variations in the activity and availability of their intertidal invertebrate prey. In: Naylor, E., Hartnoll, R. G. (eds.) Cyclic phenomena in marine plants and animals Pergamon Press, Oxford, p. 357-366

Gerritsen, A. F. C., van Heezik, Y. M. (1985). Substrate preference and substrate related foraging behaviour in three Calidris species. Neth. J. Zool. 35: 671-692

Grant, J. (1984). Sediment microtopography and shorebird foraging. Mar. Ecol. Prog. Ser. 19: 293-296

Hulscher, J. B. (1982). The oystercatcher Haematopus ostralegus as a predator of the bivalve Macoma balthica in the Dutch Wadden Sea. Ardea 70: 89-152

This article was submitted to the editor
Jensen, K. T. (1980). Aspekter af Hydrobia ulvae's og Corophium volutator's okologi i Vadehavet. M.Sc. thesis, Univ, of Aarhus

Kelsey, M. G., Hassell, M. (1989). Patch selection by dunlin on a heterogeneous mudflat. Ornis Scand. 20:250-254

Kotliar, N. B., Wiens, J. A. (1990). Multiple scales of patchiness and patch structure: a hierarchical framework for the study of heterogeneity. Oikos 59: 253-260

Kuipers, B. R., Dapper, R. (1981). Production of Crangon crangon in the tidal zone of the Dutch Wadden Sea. Neth. J. Sea Res. 15: 33-53

Morris, D. W. (1987). Ecological scale and habitat use. Ecology 68: 362-369

Myers, J. P., Williams, S. L., Pitelka, F. A. (1980). An experimental analysis of prey availability for sanderlings (Aves: Scolopacidae) feeding on sandy beach crustaceans. Can. J. Zool. 58: 1564-1574

Perkins, E. J. (1958). The hardness of the shore at Whitstable, Kent. J. Ecol. 46: 71-81

Pettigrew, J. D., Frost, B. J. (1985). A tactile fovea in the Scolopacidae? Brain Behav. Evol. 26: 185-195

Pienkowski, M. W. (1981). How foraging plovers cope with environmental effects on invertebrate behaviour and availability. In: Jones, N. V., Wolff, W. J. (eds.) Feeding strategies and survival of estuarine organisms. Plenum Press, New York, p. 179-192

Pienkowski, M. W. (1983). Changes in the foraging pattern of plovers in relation to environmental factors. Anim. Behav. 31: $244-264$

Quammen, M. L. (1982). Influence of subtle substrate differences on feeding by shorebirds on intertidal mudflats Mar. Biol. 71: 339-343

Readings, C. J., McGrorty, S. (1978). Seasonal variation in the burying depth of Macoma balthica (L.) and its accessibility to wading birds. Estuar. coast. mar. Sci. 6: 135-144

Rumohr, H., Brey, T., Ankar, S. (1987). A compilation of biometric conversion factors for benthic invertebrates of the Baltic Sea. Baltic Marine Biologists, Kiel, Publication no. 9

Snedecor, G. W., Cochran, W. G. (1989). Statistical methods. Iowa State Univ. Press, Ames

Sokal, R. R., Rohlf, F. J. (1981). Biometry. W. H. Freeman and Co., New York

Tjallingii, S. J. (1972). Habitat selection of the avocet (Recurvirostra avocetta) in relation to feeding. In: Voous, K. H. (ed.) Proc. XVth int. Orn. Congr. E. J. Brill, London, p. 696-697

Trush, S. F., Hewitt, J. E., Pridmore, R. D. (1989). Patterns in the spartial arrangements of polychaetes and bivalves in intertidal sandflats. Mar. Biol. 102: 529-535

Trush, S. F. (1991). Spartial pattern in soft-bottom communities. Trends Ecol. Evol. (TREE) 6: 75-79

Vader, W. J. M. (1964). A preliminary investigation into the reactions of the infauna of the tidal flats to tida! fluctuations in water level. Neth. J. Sea Res. 2: 189-222

Worrall, D. H. (1984). Diet of the dunlin Calidris alpina in the Severn Estuary. Bird Stud. 31: 203-212

Zwarts, L., Esselink, P. (1989). Versatility of male curlews Numenius arquata preying upon Nereis diversicolor: deploying contrasting capture modes dependent on prey availability. Mar. Ecol. Prog. Ser. 56: 255-269

Zwarts, L., Wanink, J. H. (1991). The macrobenthos fraction accessible to waders may represent marginal prey. Oecologia 87: 581-587 